Technological University Dublin ARROW@TU Dublin

\title{
The Problems faced by Higher Education Institutions because of the Constantly Changing Objectives, sometimes Imposed Externally, sometimes Self-imposed
}

Frank McMahon

Technological University Dublin, frank.mcmahon@tudublin.ie

Follow this and additional works at: https://arrow.tudublin.ie/diraabk

Part of the Education Commons

\section{Recommended Citation}

McMahon, F.: The Problems Faced by Higher Education Institutions Because of the Constantly Changing Objectives, Sometimes Imposed Externally, Sometimes Self-Imposed. in Issues of Contemporary Ecuation (Preston, S. (ed). Rodopi, 2005.

This Book Chapter is brought to you for free and open access by the Directorate of Academic Affairs at ARROW@TU Dublin. It has been accepted for inclusion in Books/Book chapters by an authorized administrator of ARROW@TU Dublin. For more information, please contact arrow.admin@tudublin.ie, aisling.coyne@tudublin.ie,gerard.connolly@tudublin.ie.

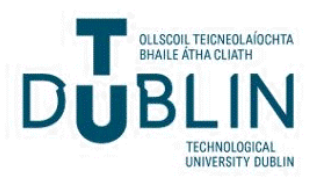




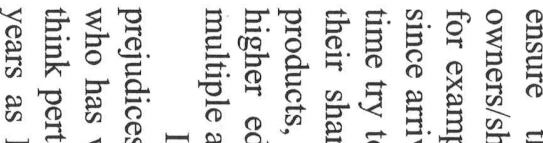

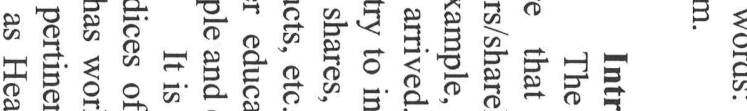
ह气 突

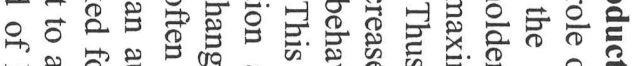

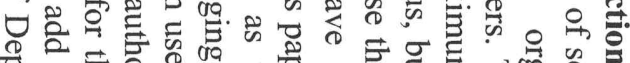

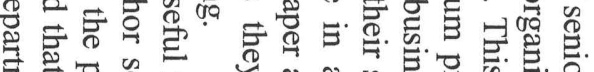

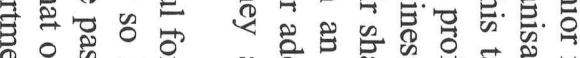

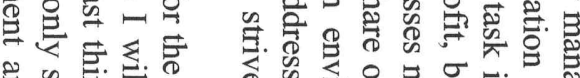

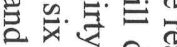

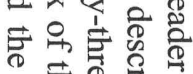

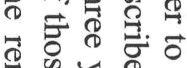

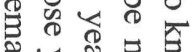

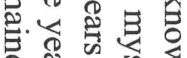

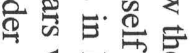

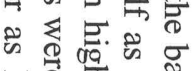
$\forall$ के

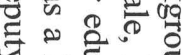

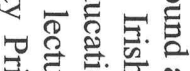

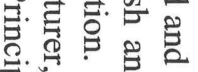

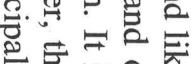

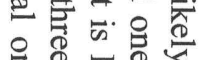

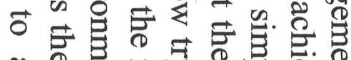

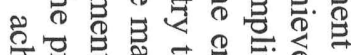

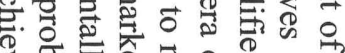

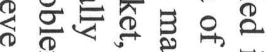

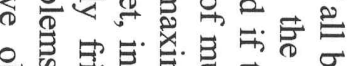

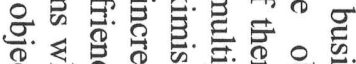

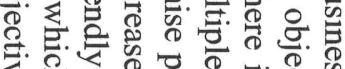
ए

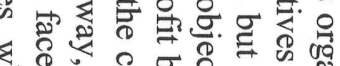
ङ ठ

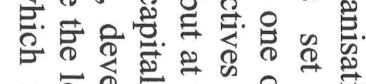

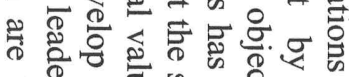

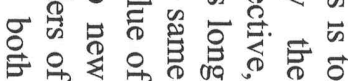

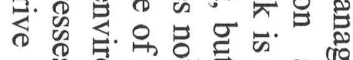

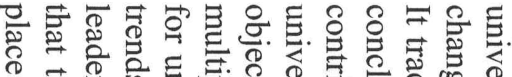

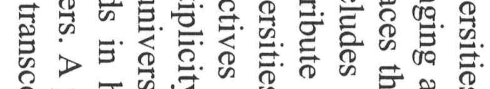

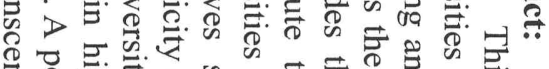

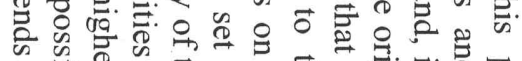

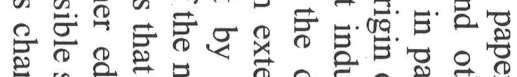

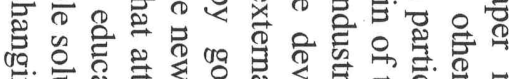

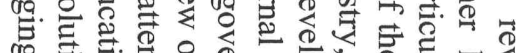

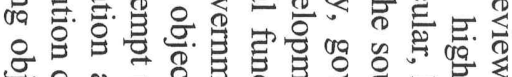

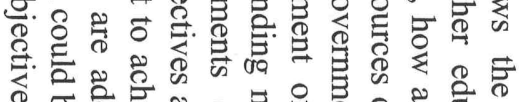

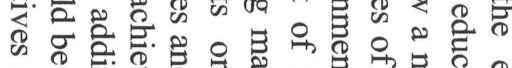

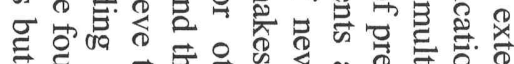

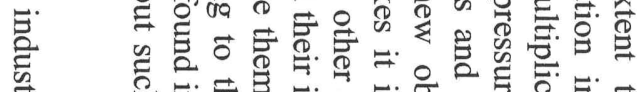

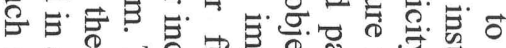

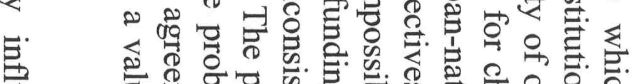

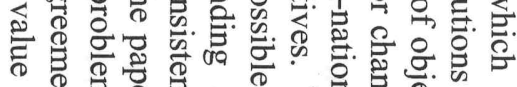

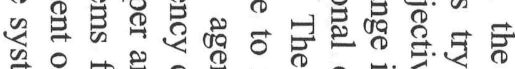

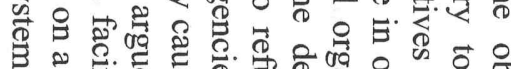

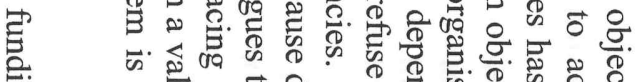

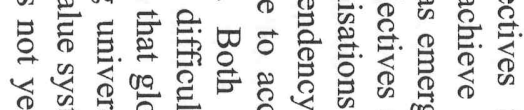

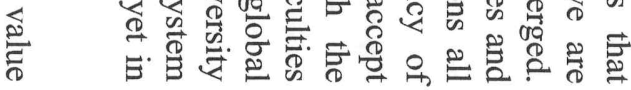




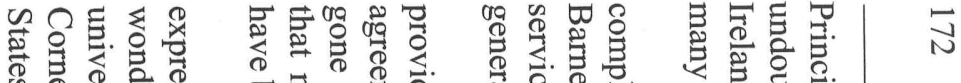

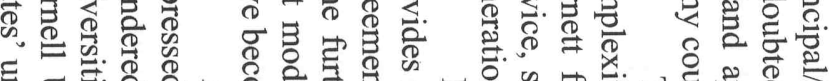

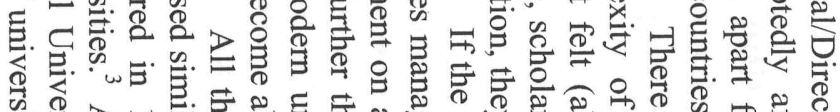

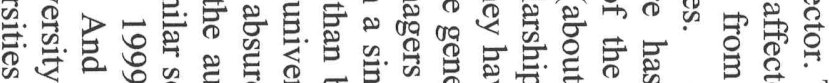

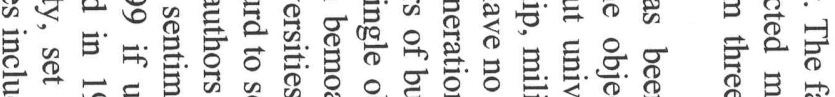

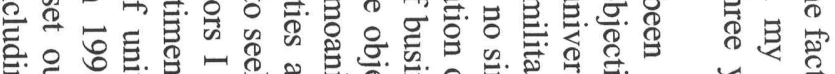

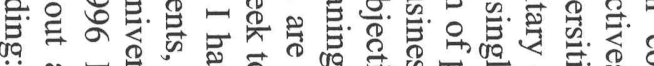

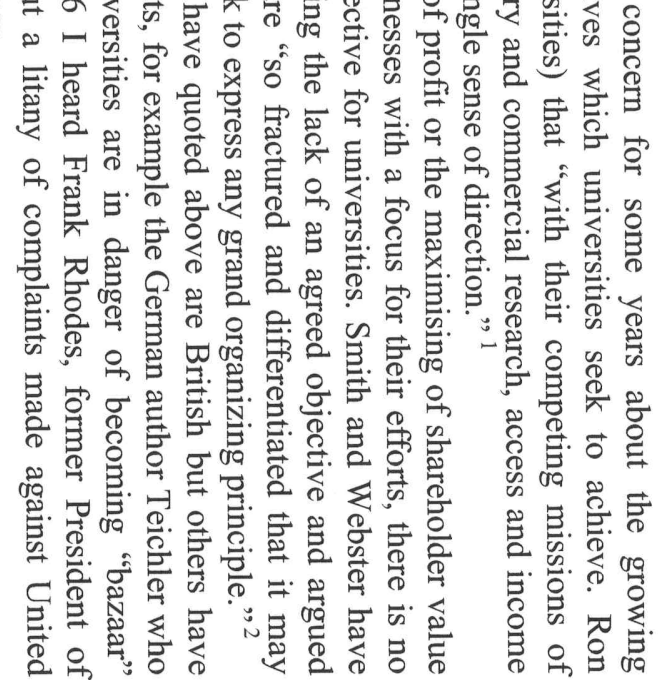
密要声 ज. $\overrightarrow{0}, \vec{B}$ त्र 공 害总总

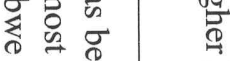

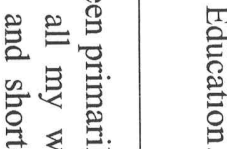

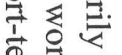
兽完卷

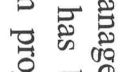
ㄱ. का

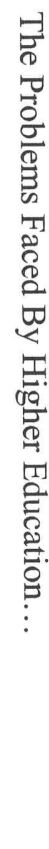

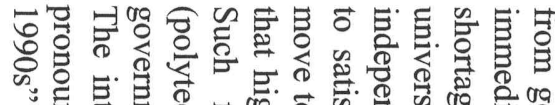

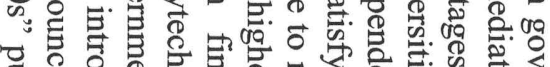

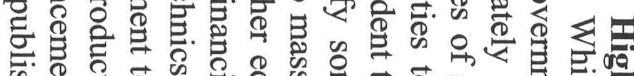

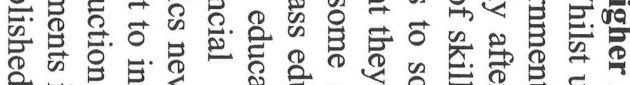

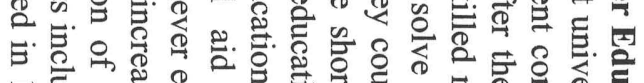

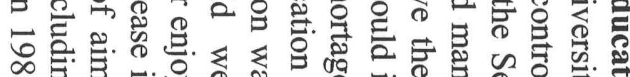

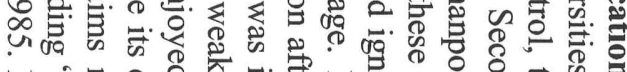

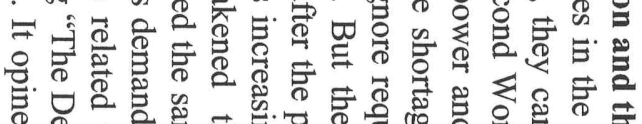

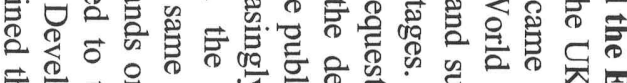

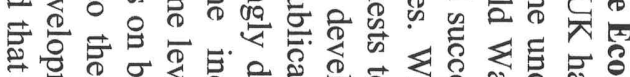

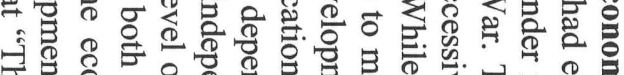

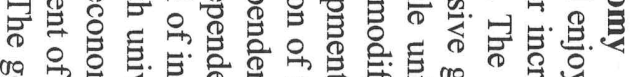

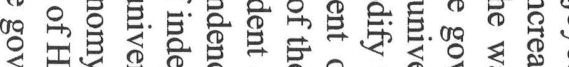

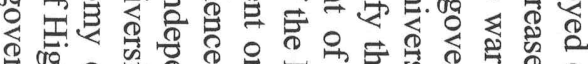

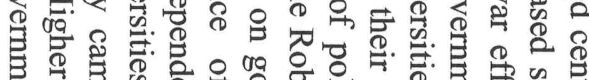

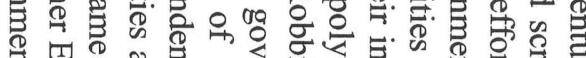

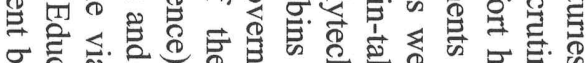
更不

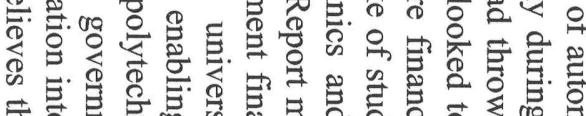

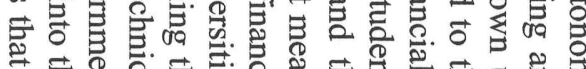

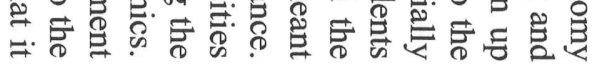

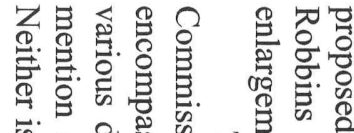

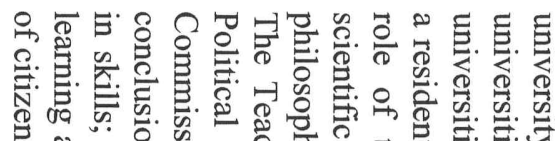

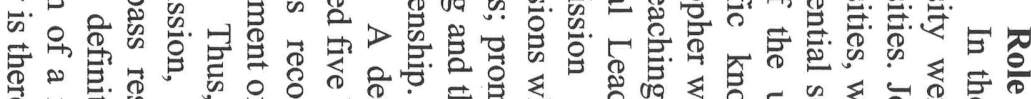
क्व

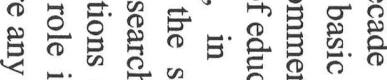

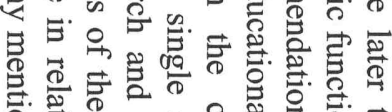

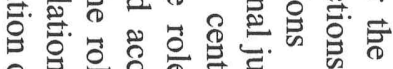

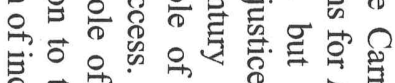

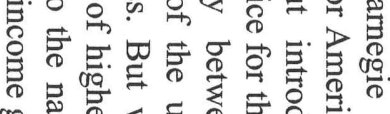

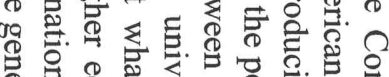

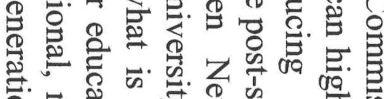

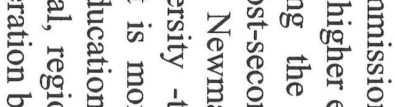

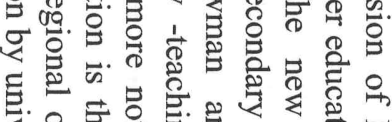

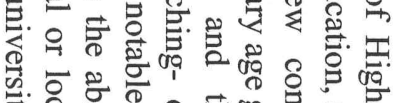

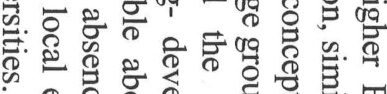

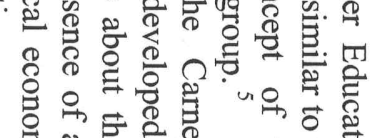

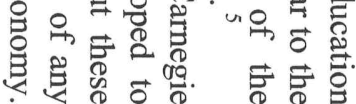

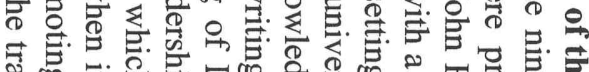

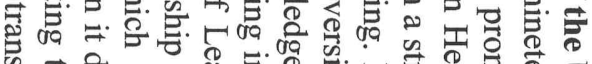

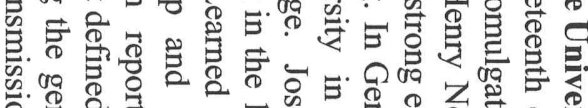

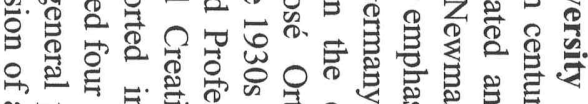

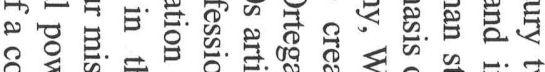

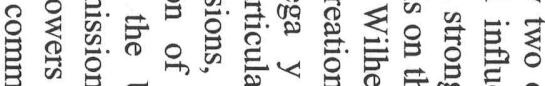

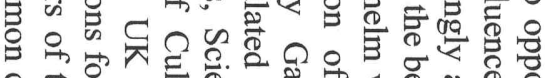

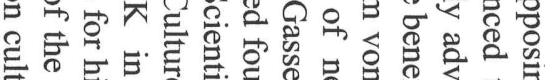

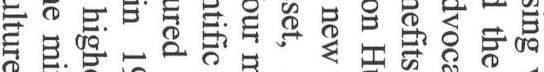

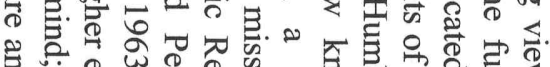

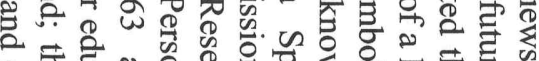
ठ 荌.

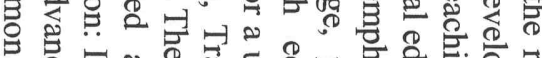

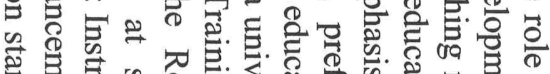

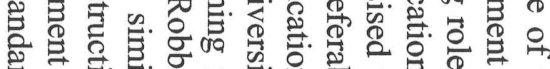

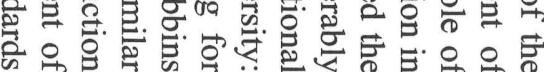




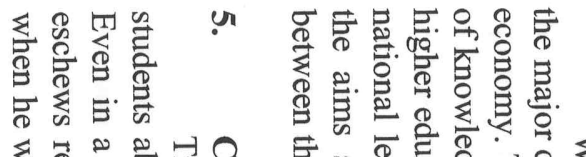

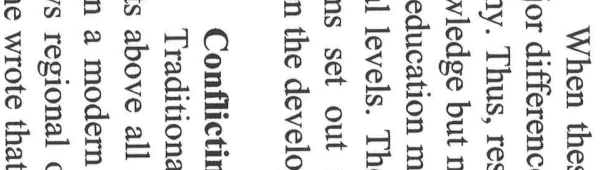

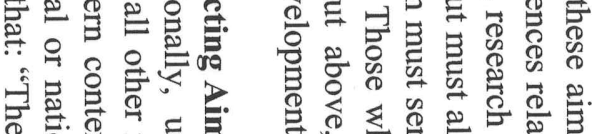

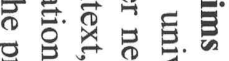

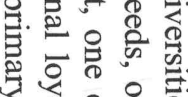

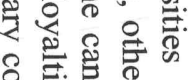

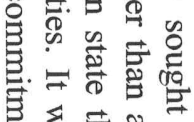
10

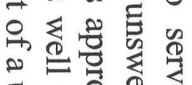
(1)

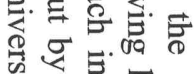
(1)

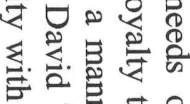

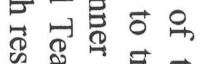

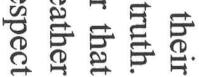

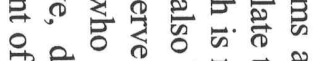

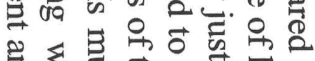

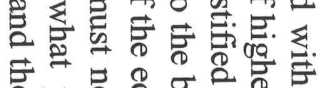

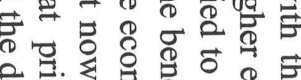

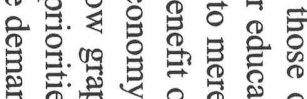

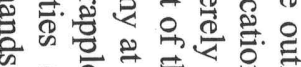

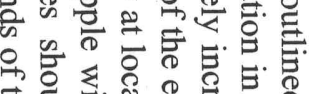

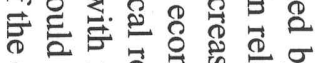

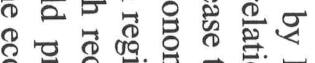

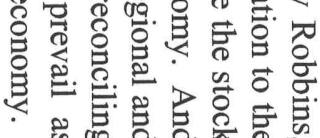

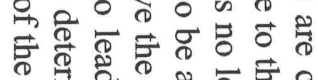

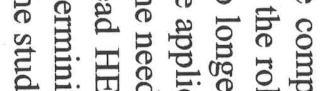

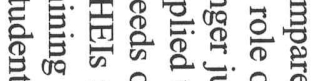

$\oplus \quad \omega \quad \sim$

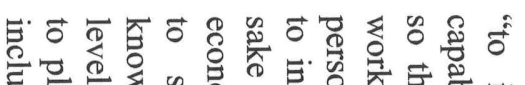

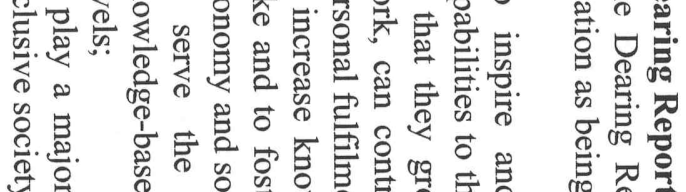

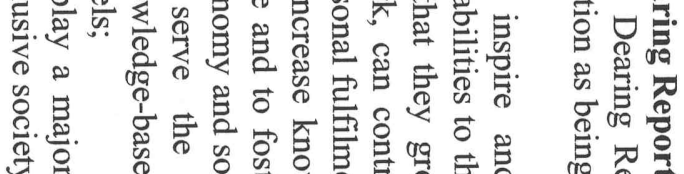

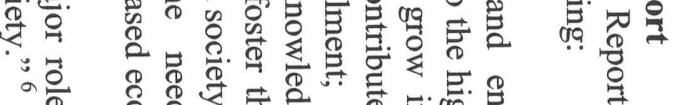

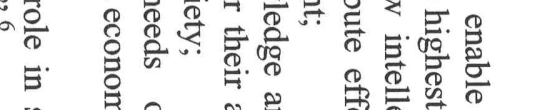

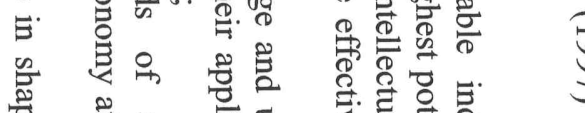

宓.

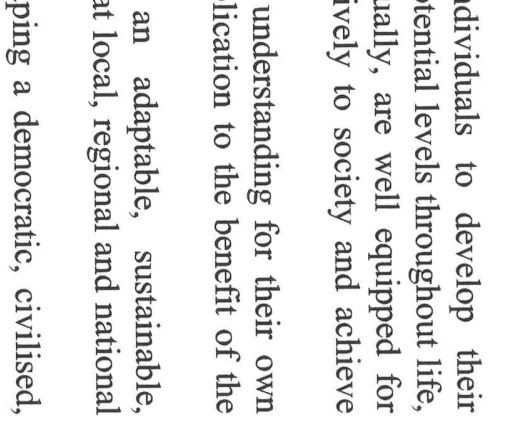

疍

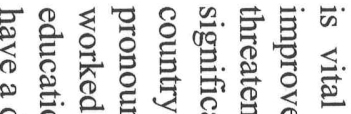

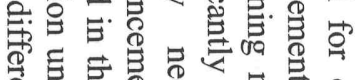

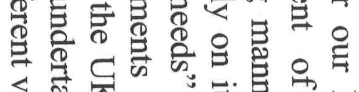

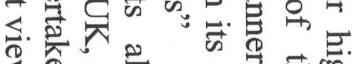

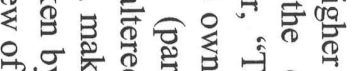

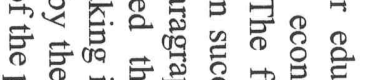

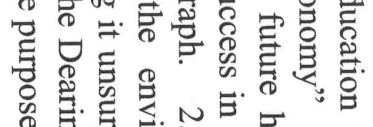

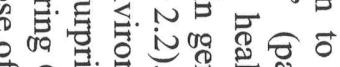

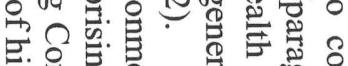

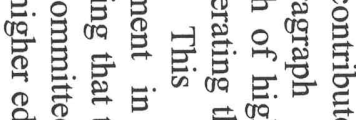

语官

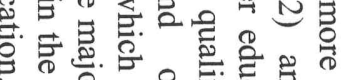

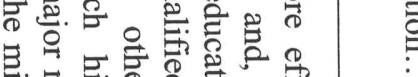
ㄴ.

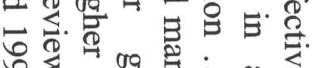
造 \%

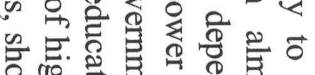

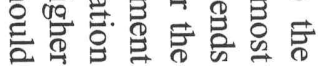

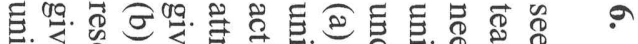

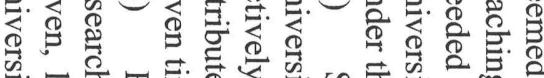

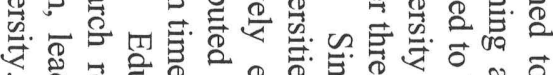

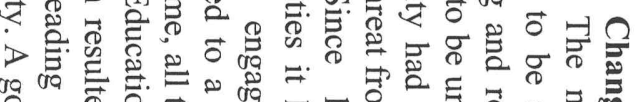

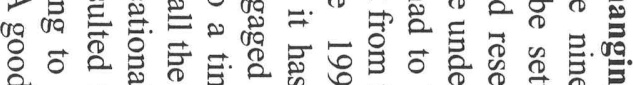
מ

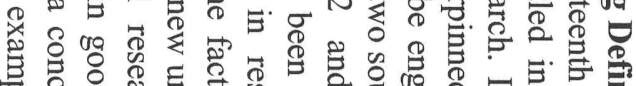

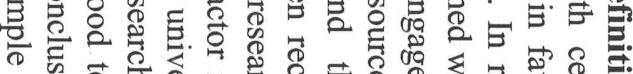

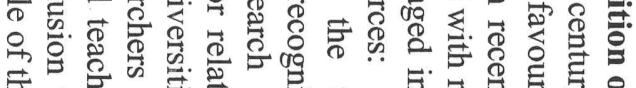

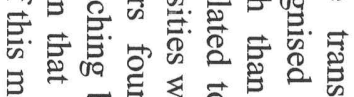

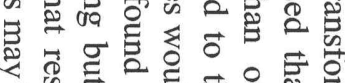

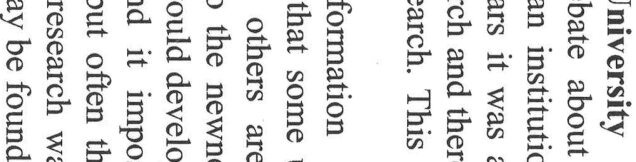

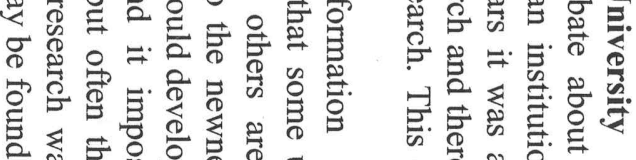

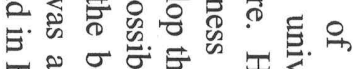

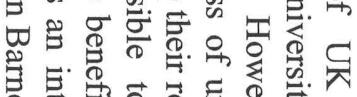

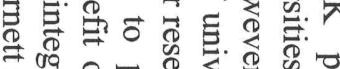

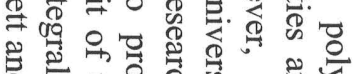

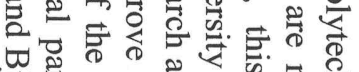

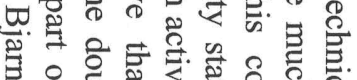

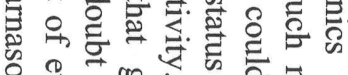

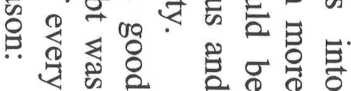

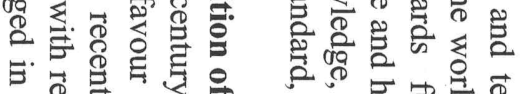

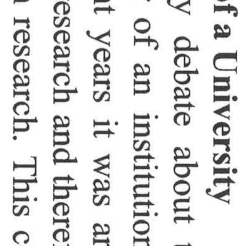

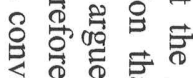

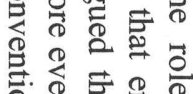

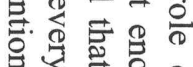

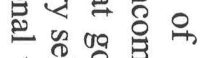

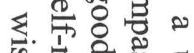

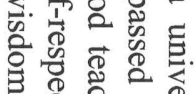

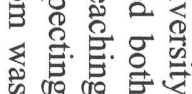
声.

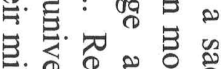

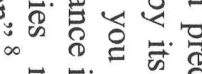

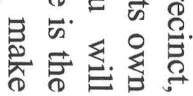

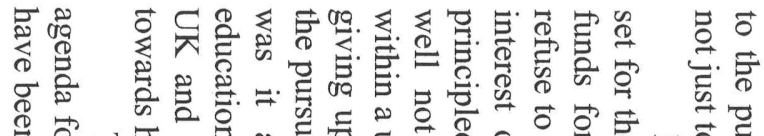

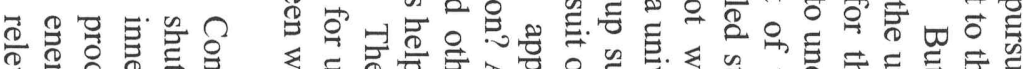

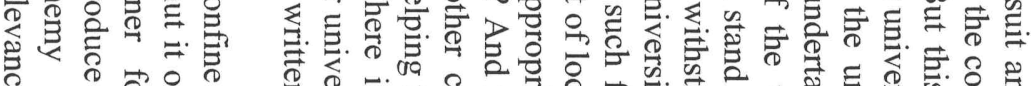

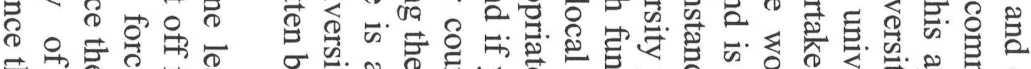

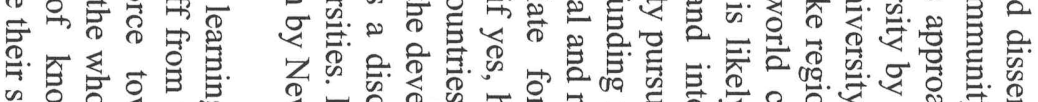

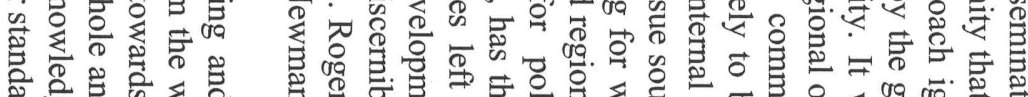

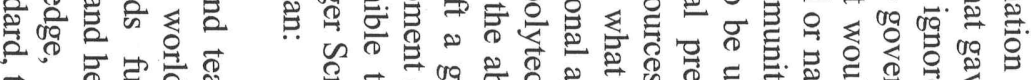

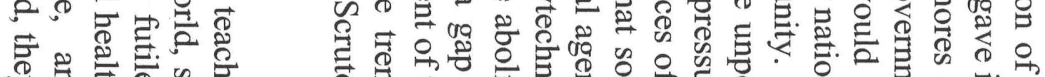

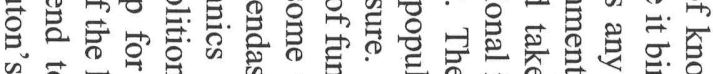

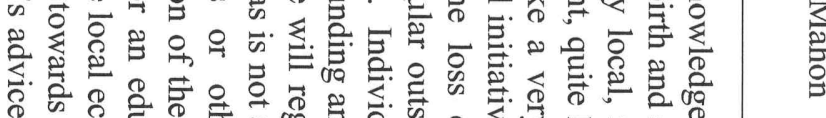

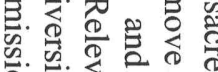

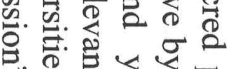

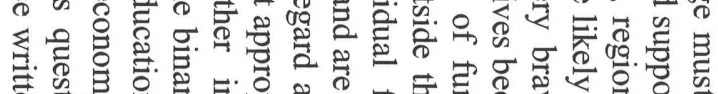

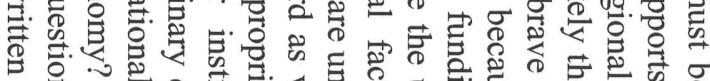

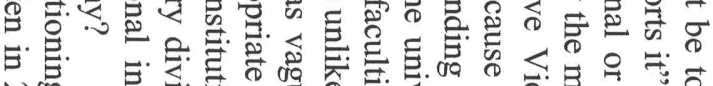

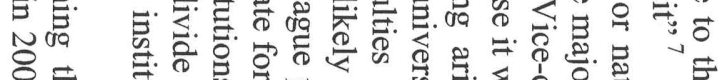

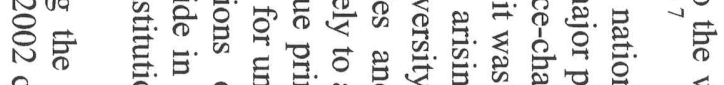

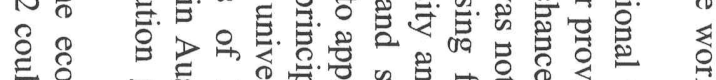

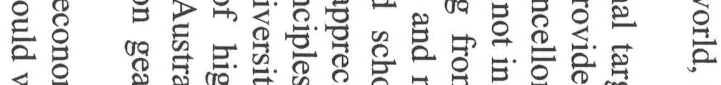

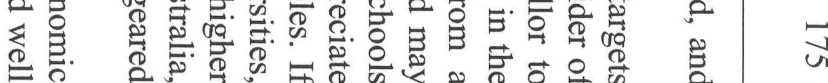

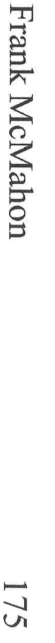




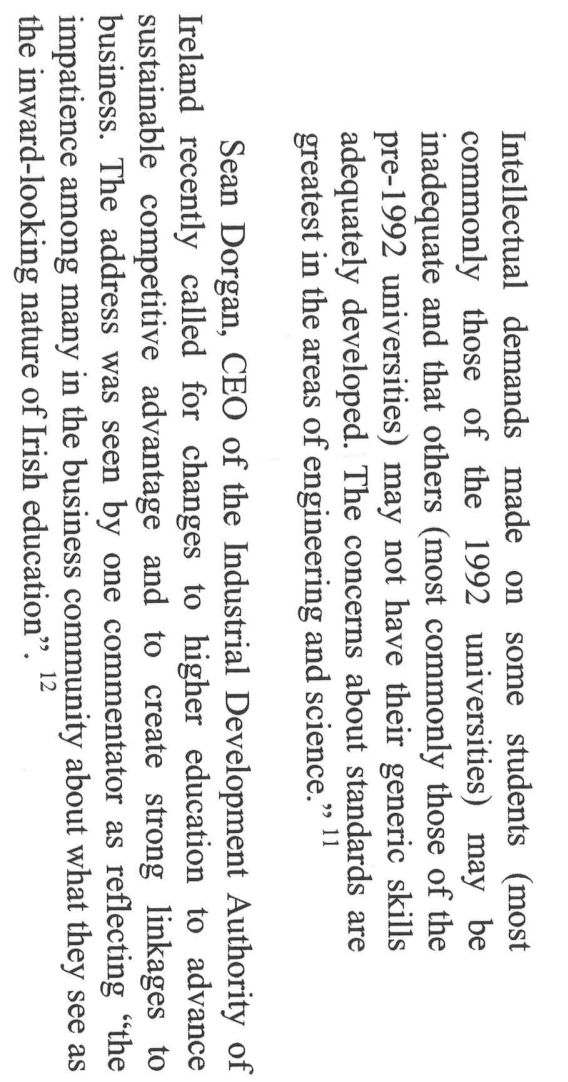

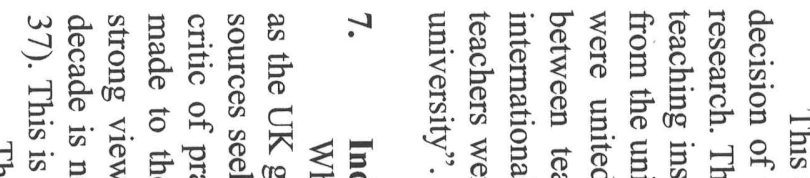

รั

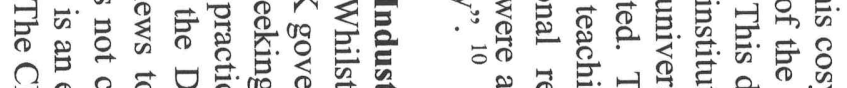

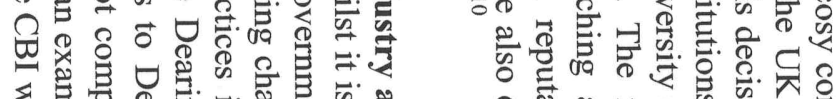
MIn:

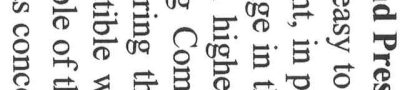

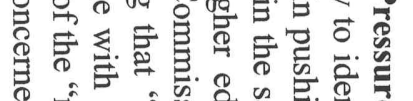
tenting

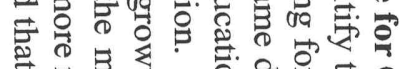

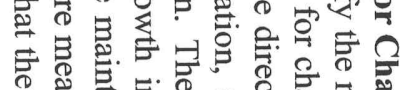

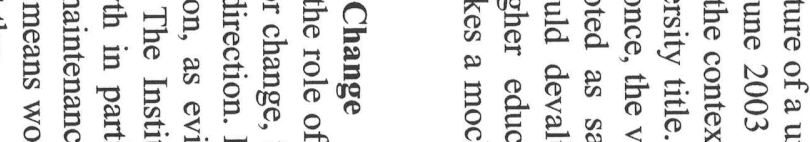

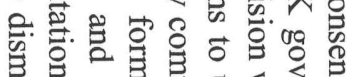

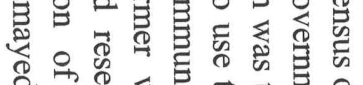

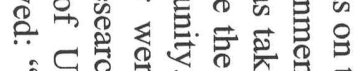

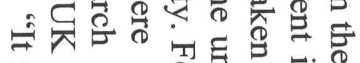

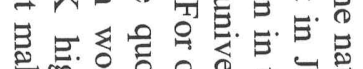

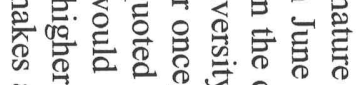
势

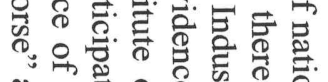

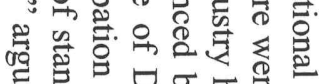
要

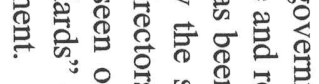

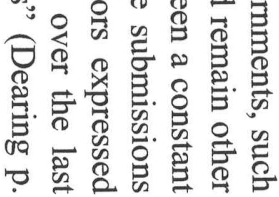

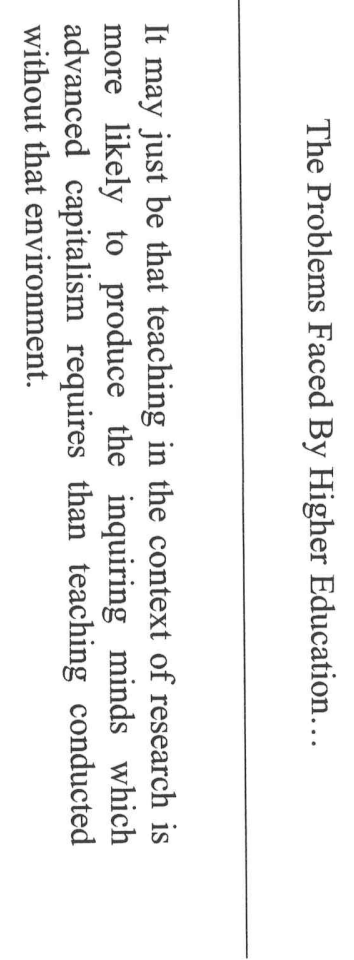

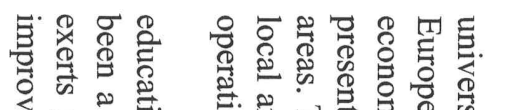

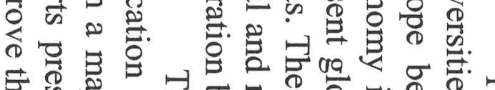

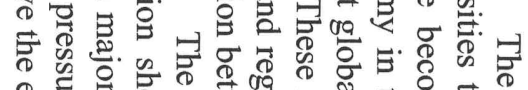

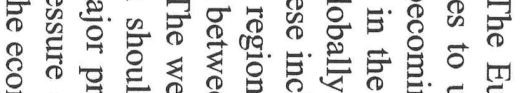

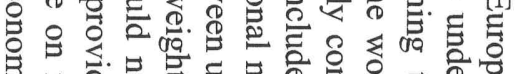

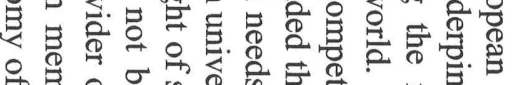

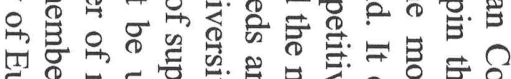

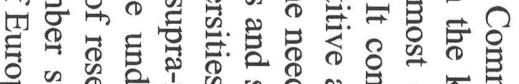
shy

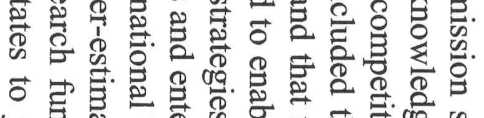

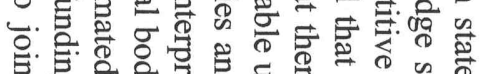

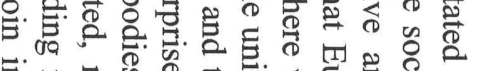

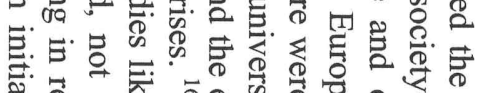

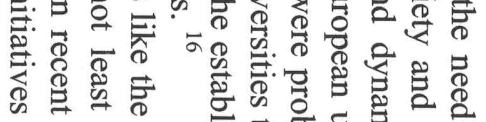

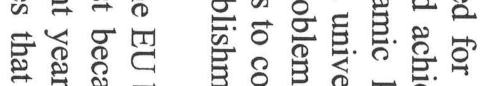

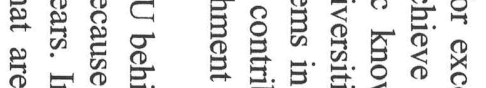

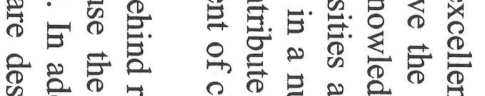

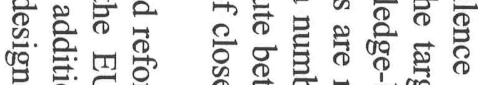

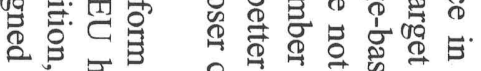

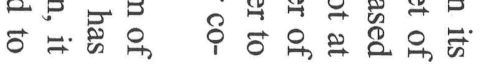

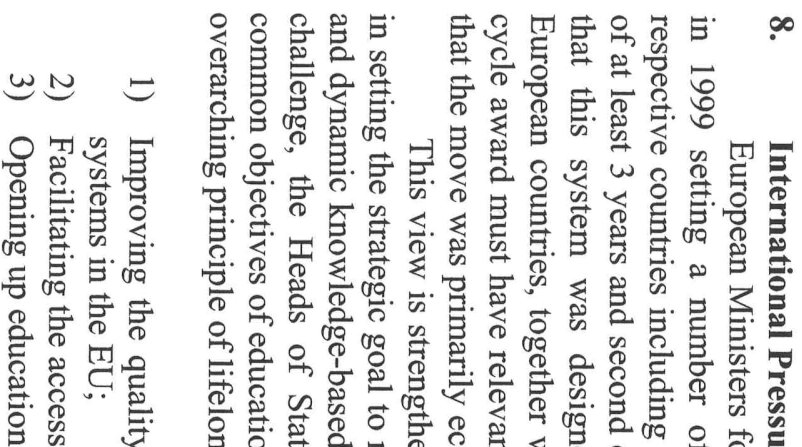

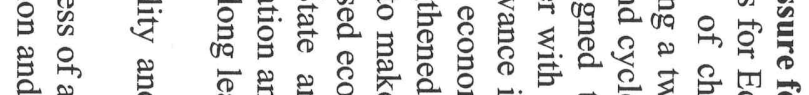

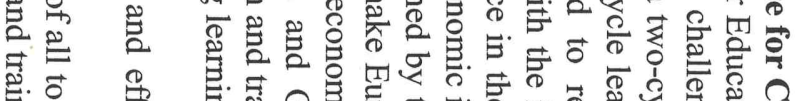

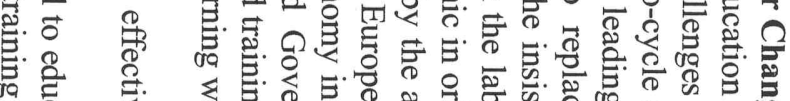

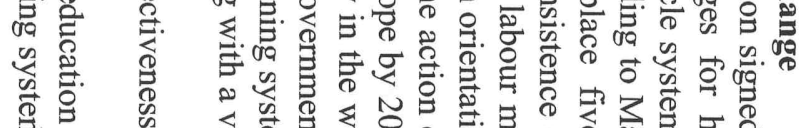

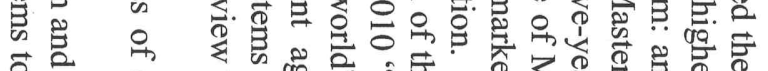

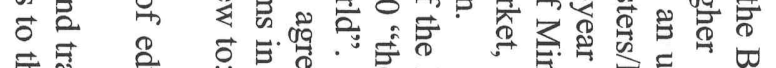

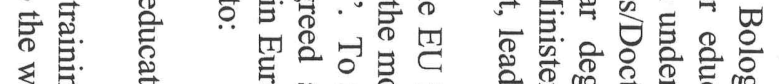

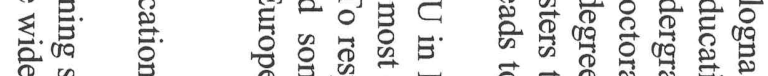

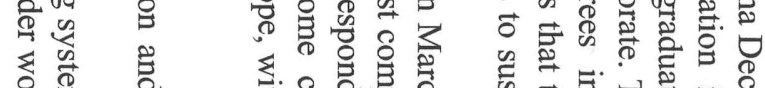

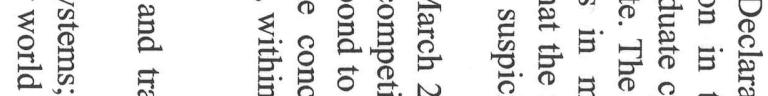

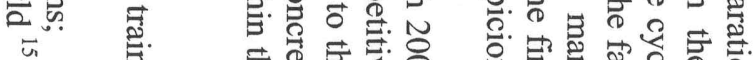

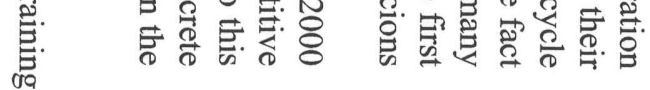

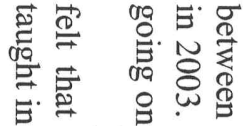

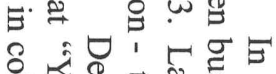

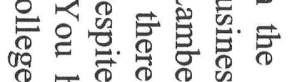
क ज्ञ

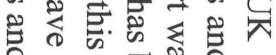

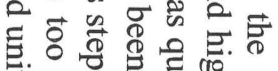
궁요

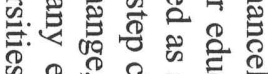

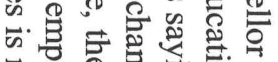

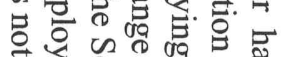

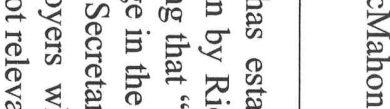

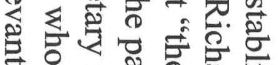

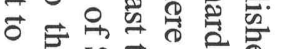

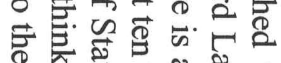

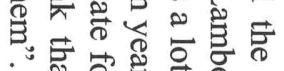

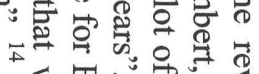

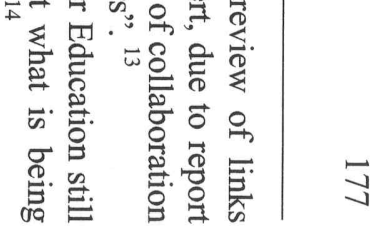




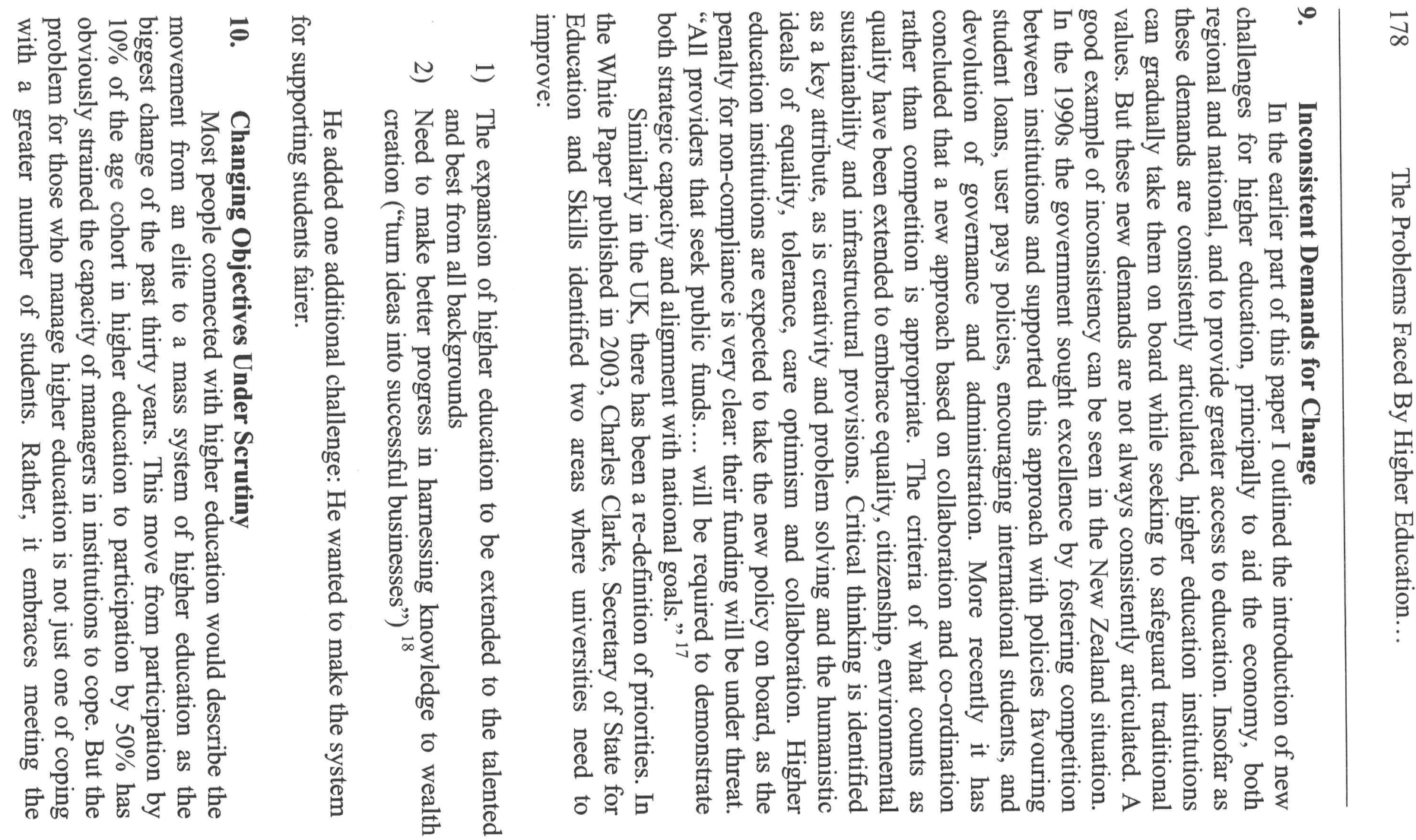

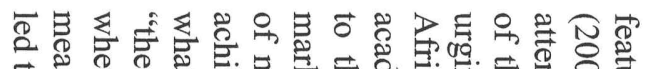

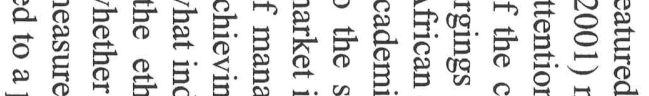

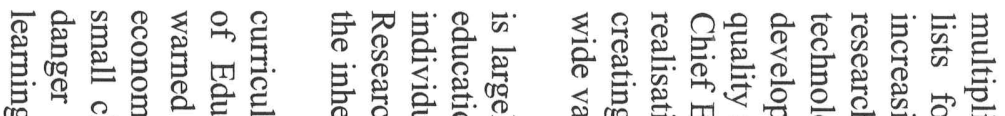

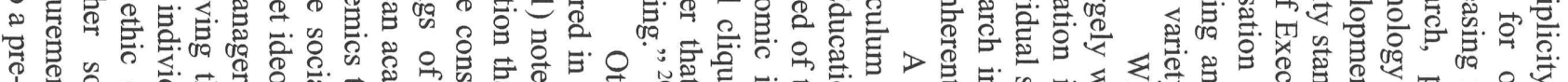

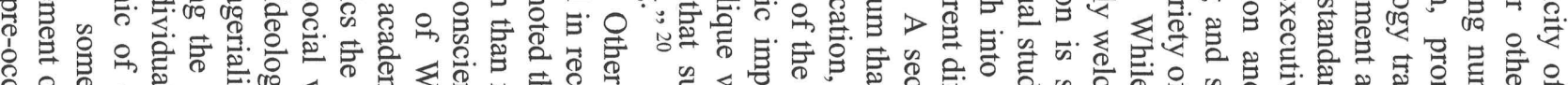

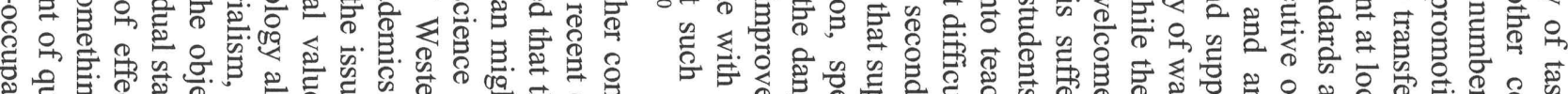

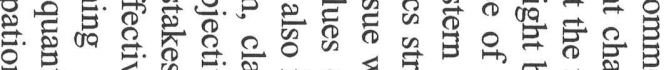

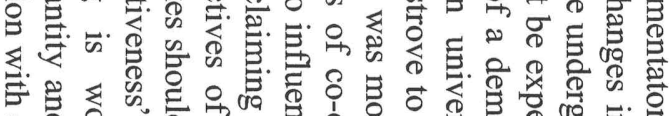

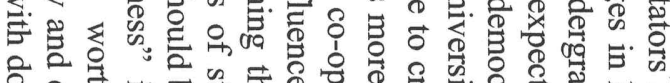

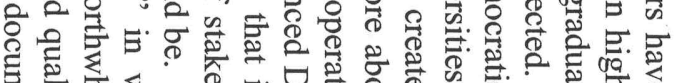

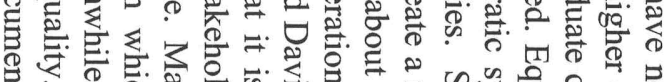

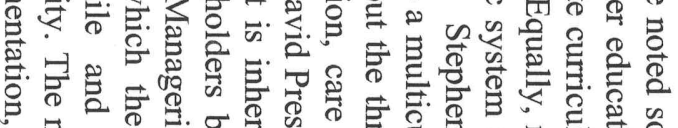

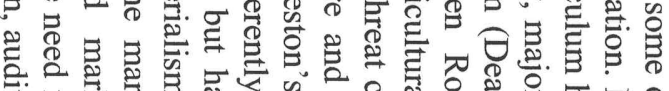

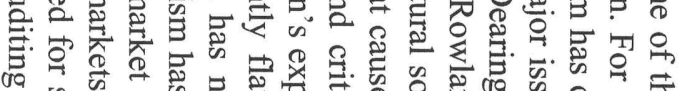

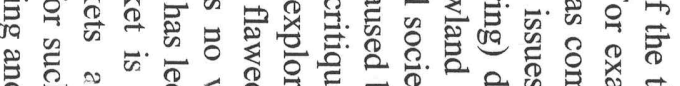

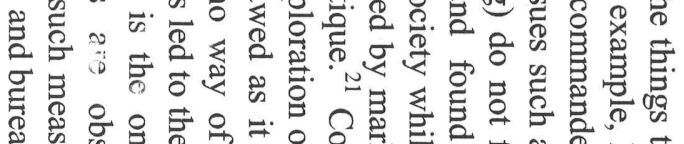

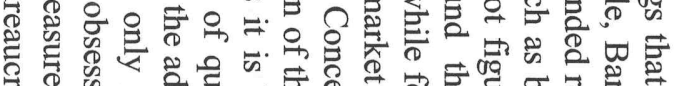

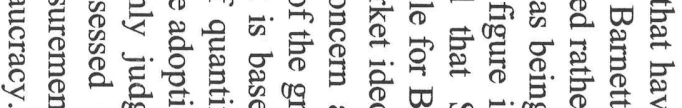

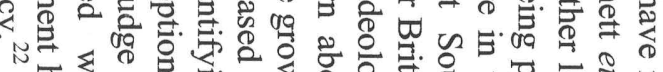

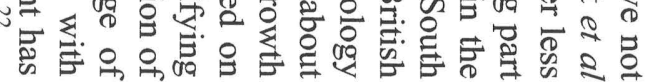

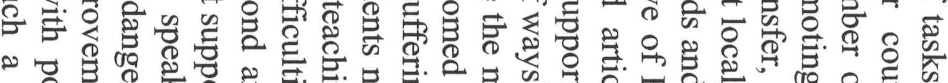

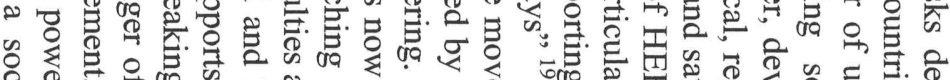

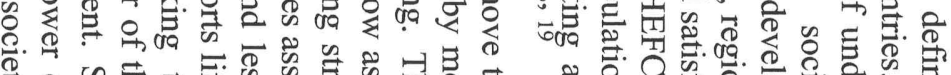

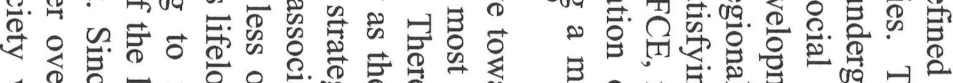

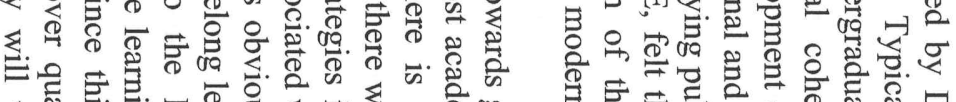

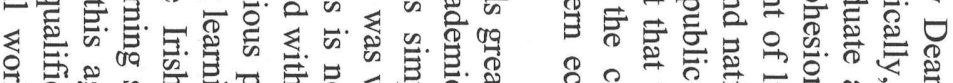

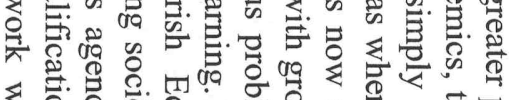

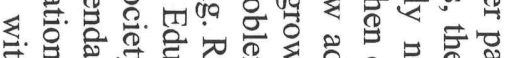

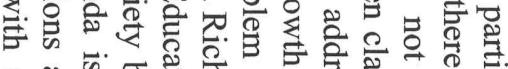

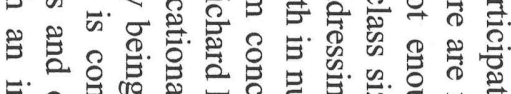

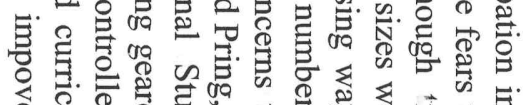

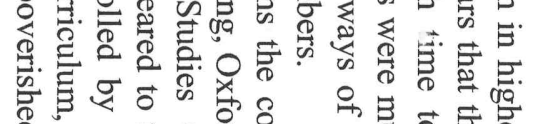
م

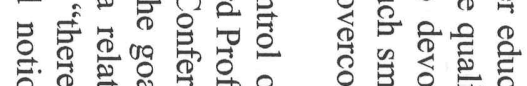

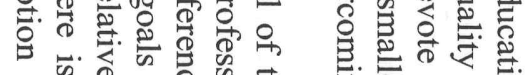

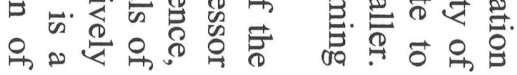

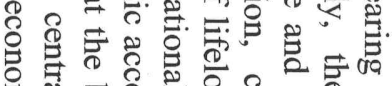

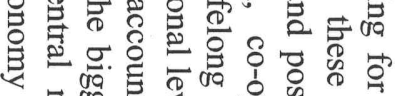

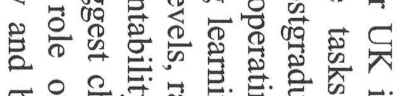

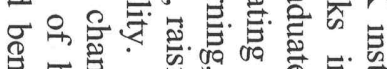

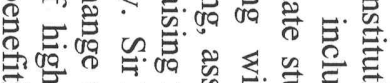

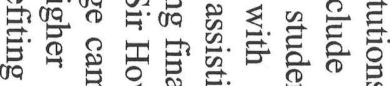

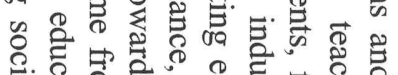

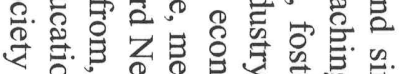

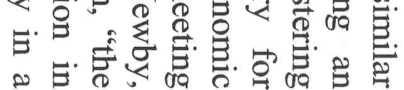




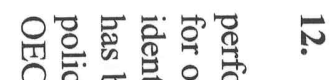

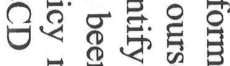

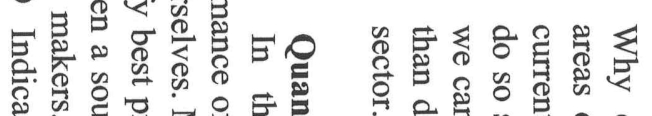

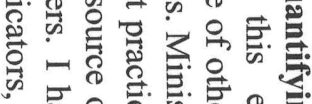
N

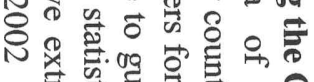

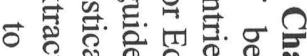
.

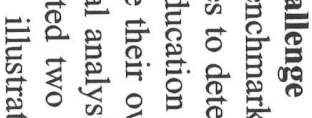

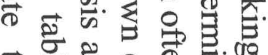

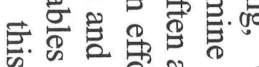

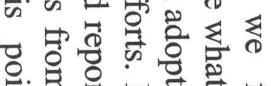

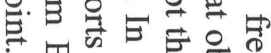

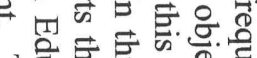

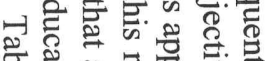

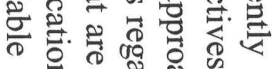

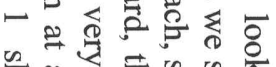

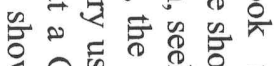

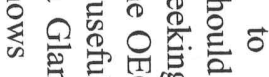

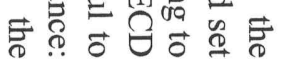

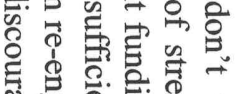

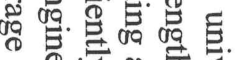

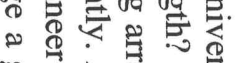

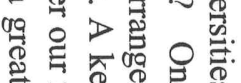

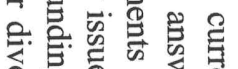

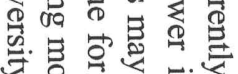

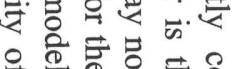

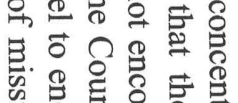

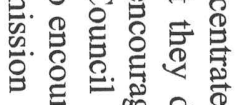

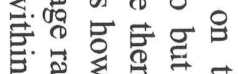

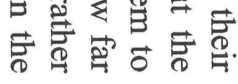

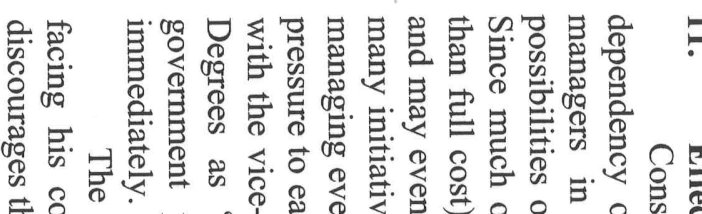
는 承

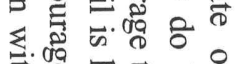

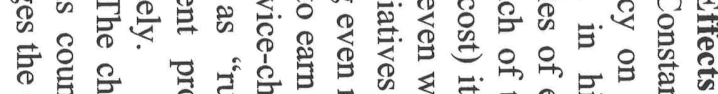

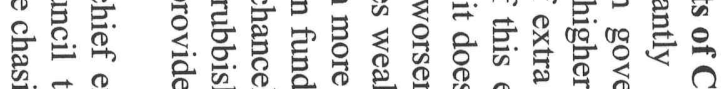

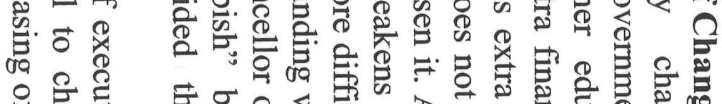

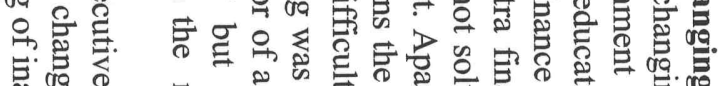

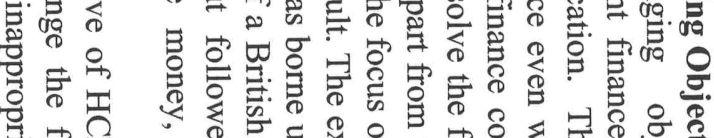

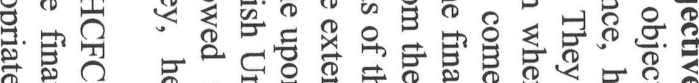

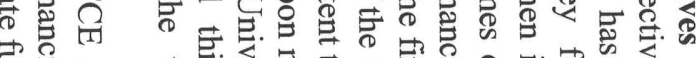

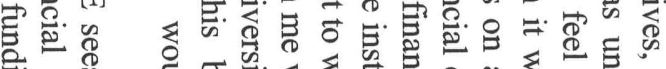
急

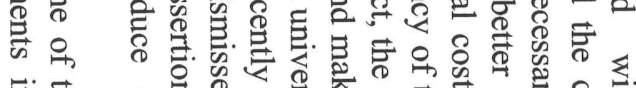
클

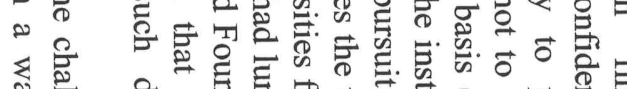

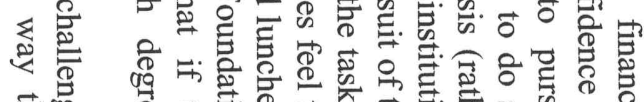

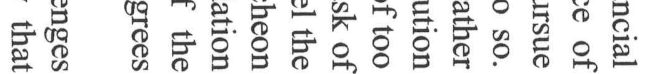

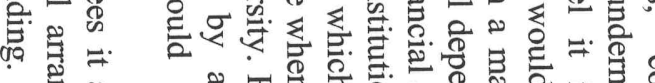
毠

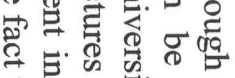

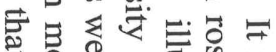

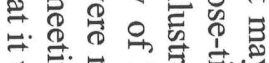
¿

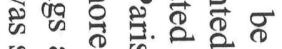

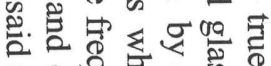

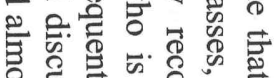

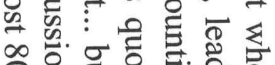

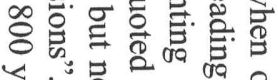

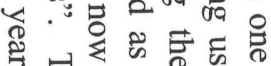

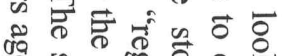

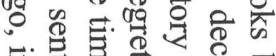

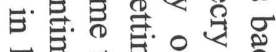

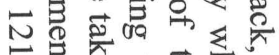

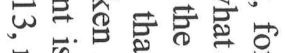

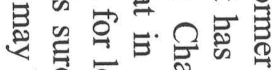

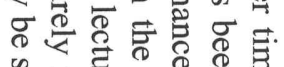

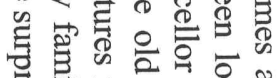

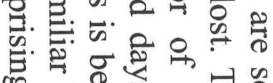
पa

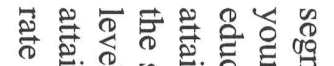

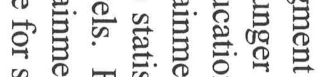

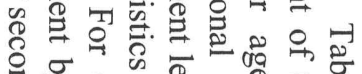

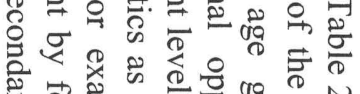

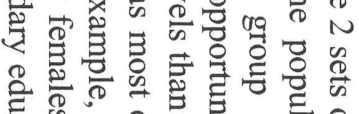
领

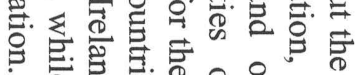

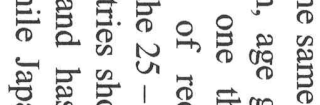

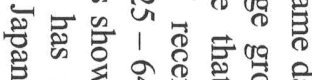

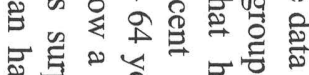

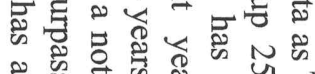
萢.

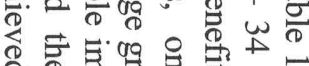

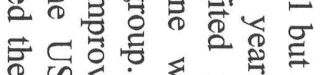

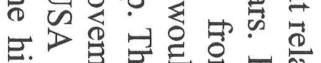

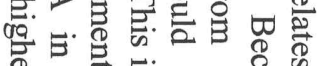

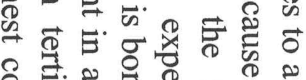

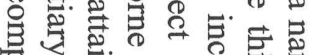

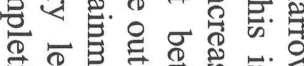

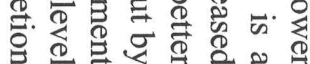

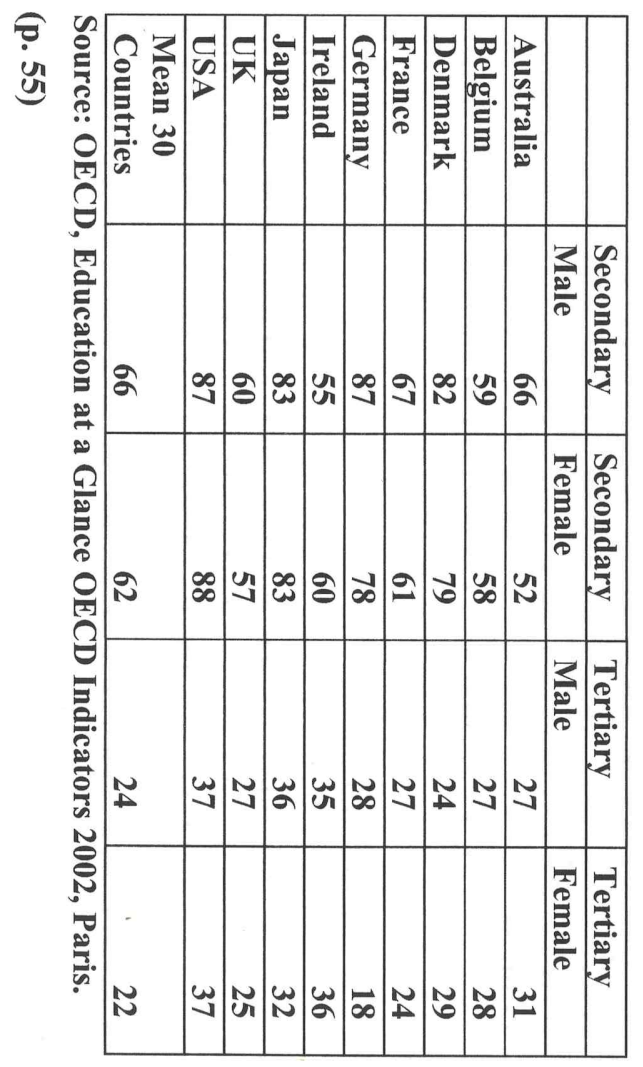

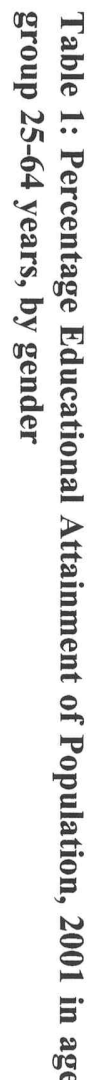

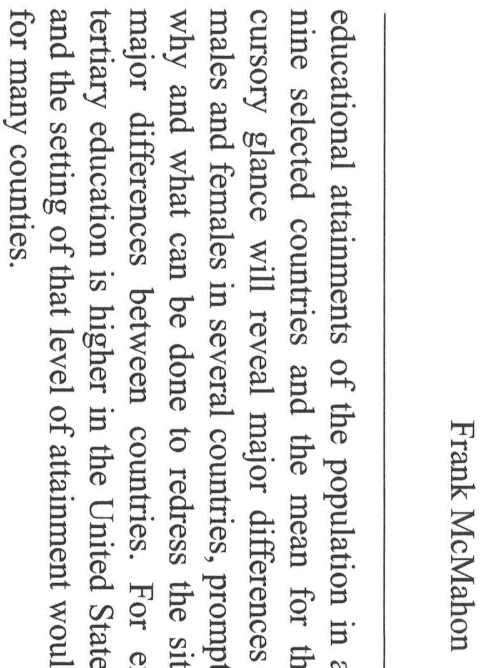

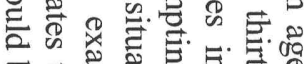

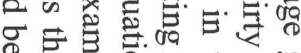

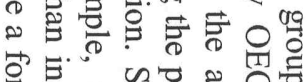

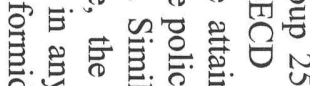

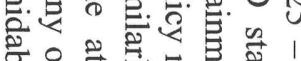

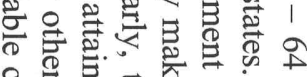

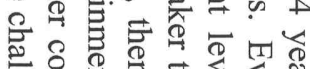

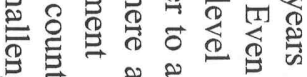

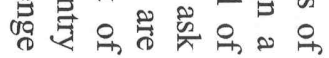




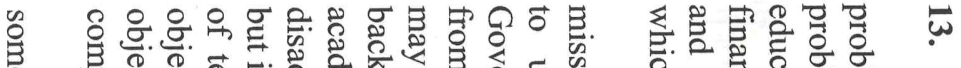

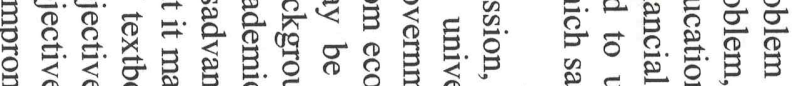

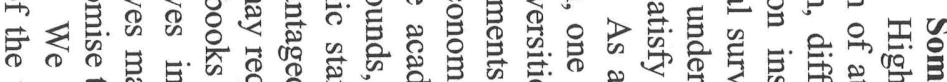

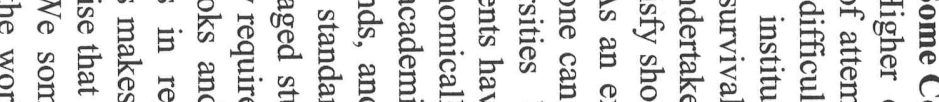

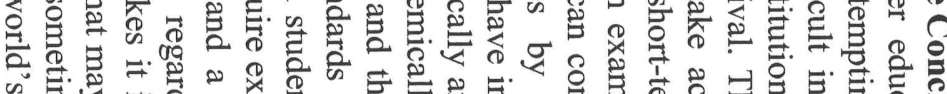

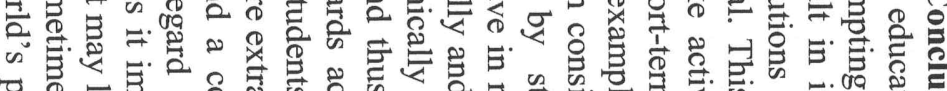

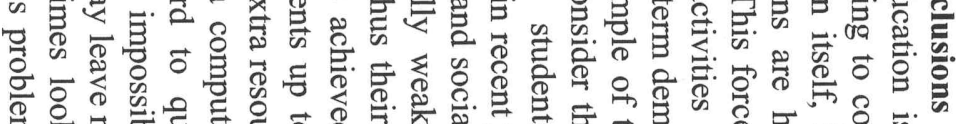

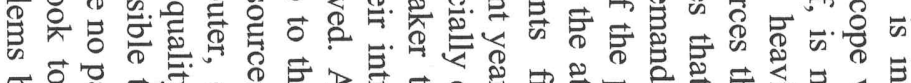

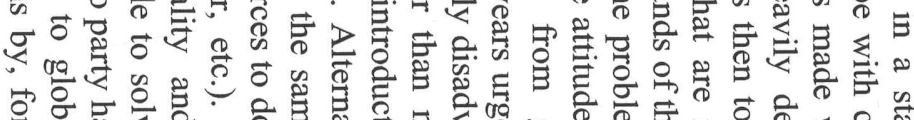

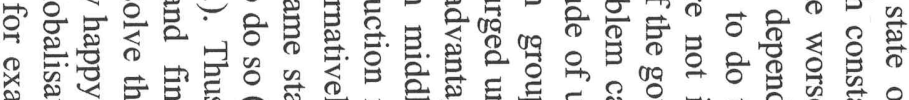

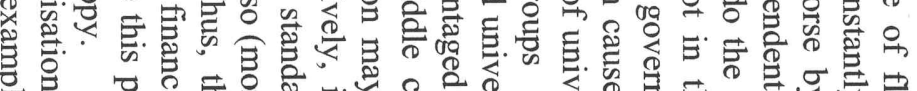

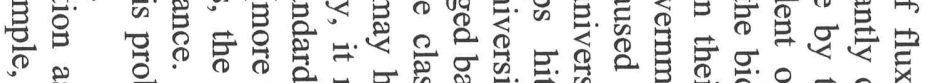

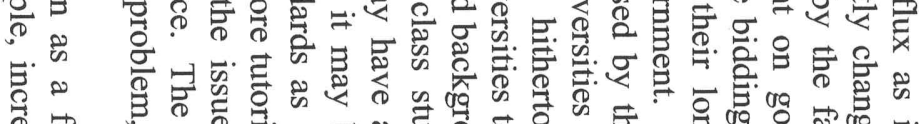

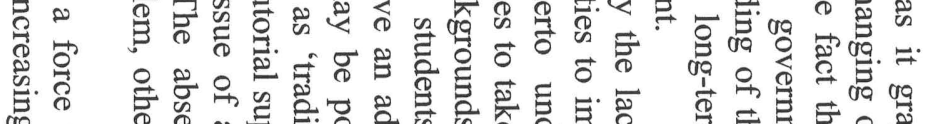

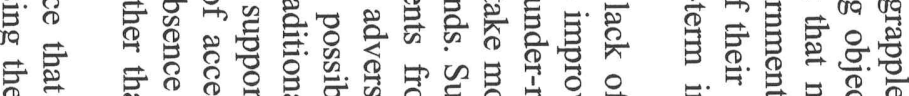

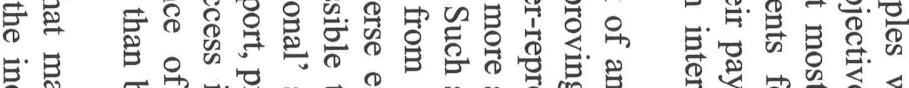

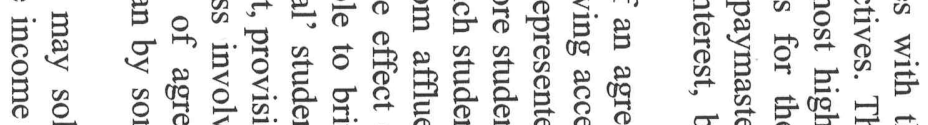

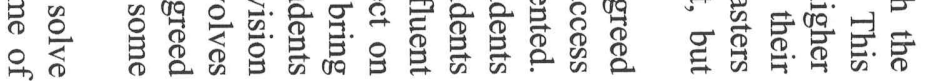

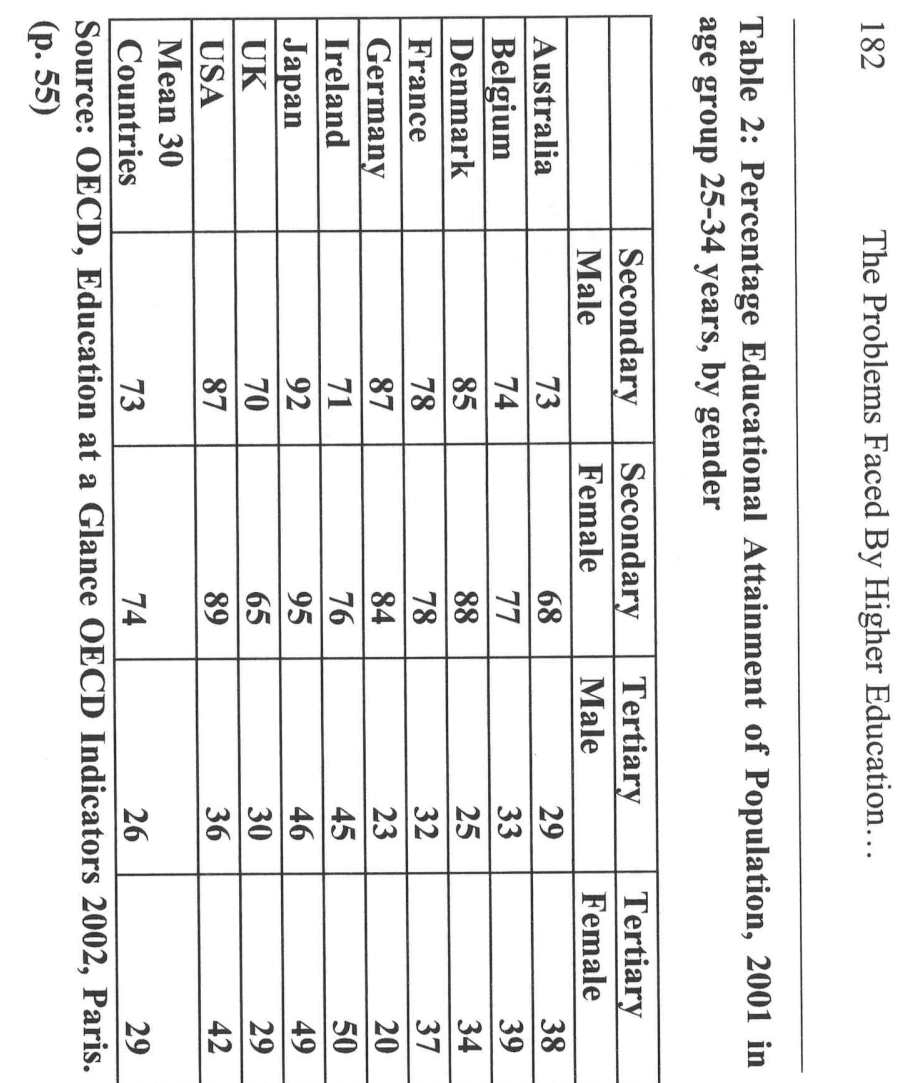

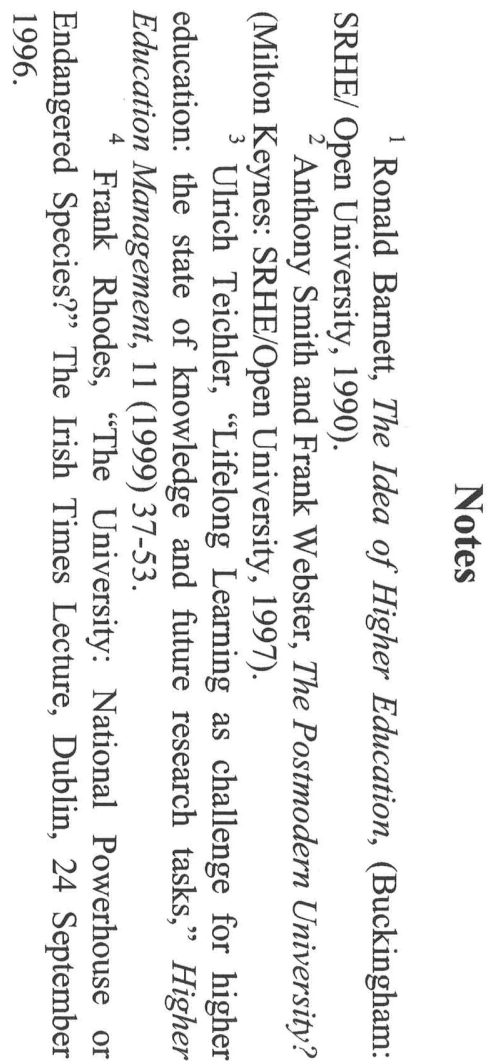

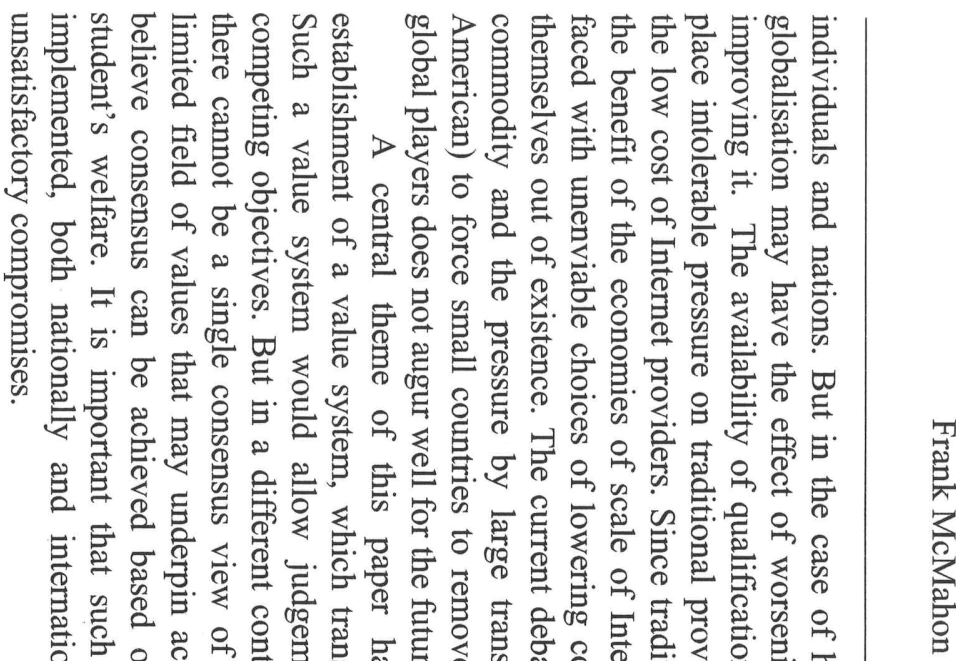

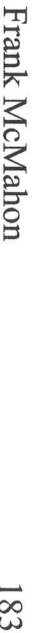




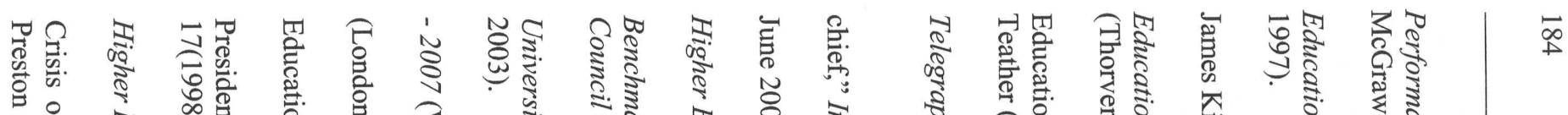

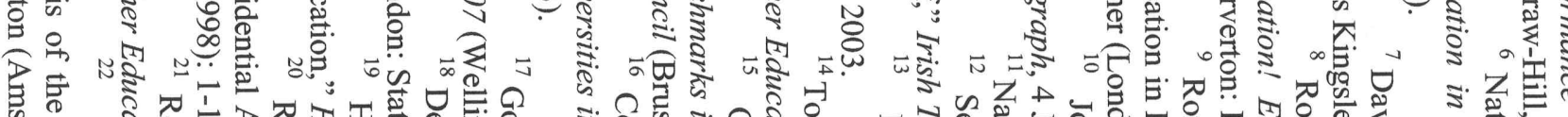

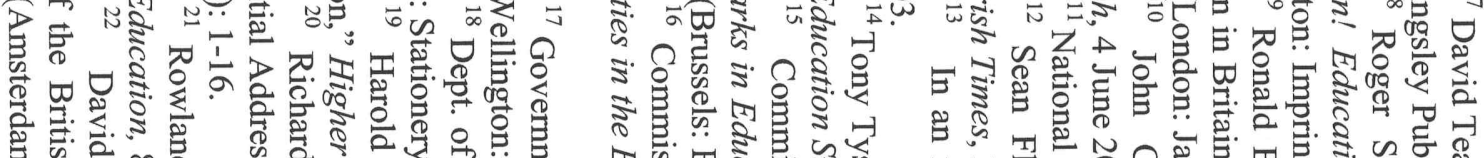

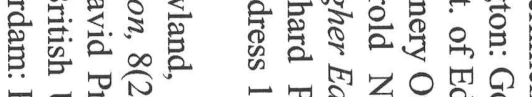

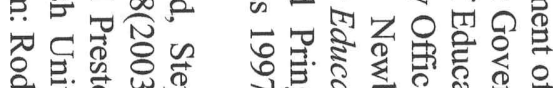

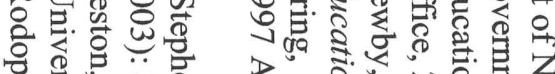

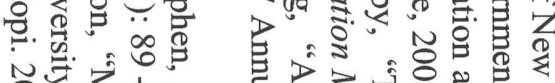

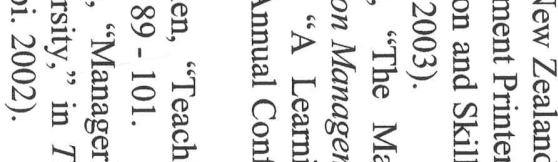

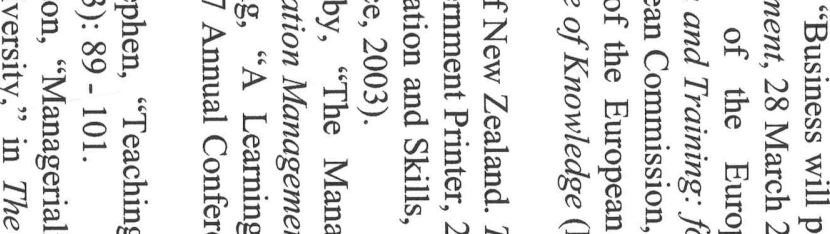

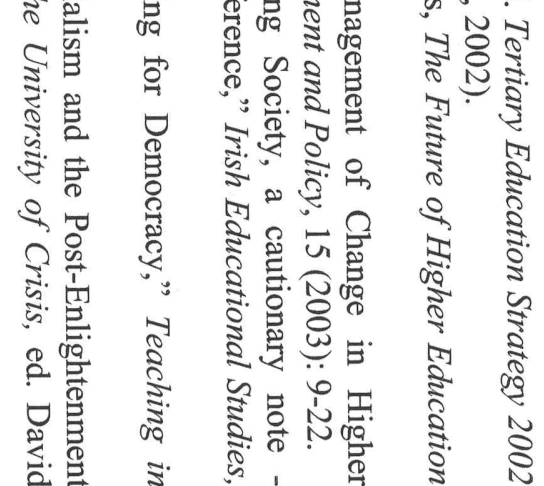
본. ₹.

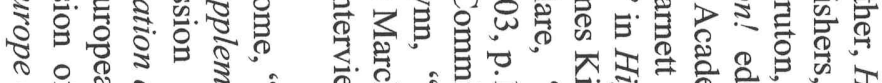

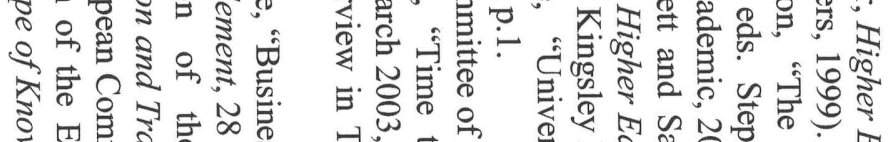

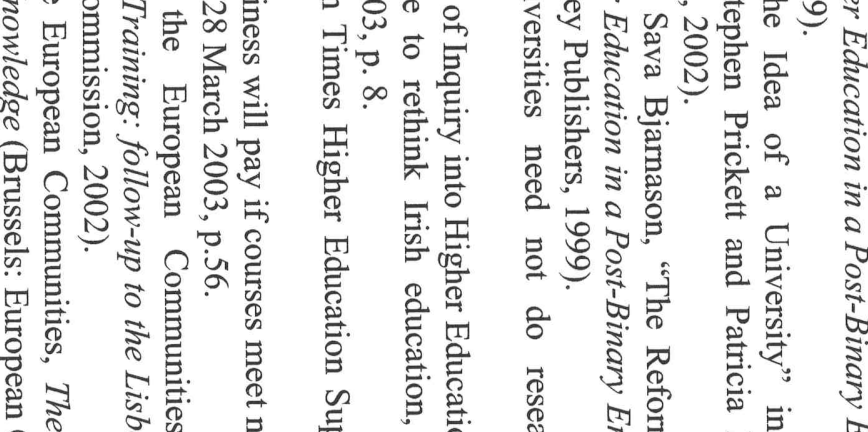

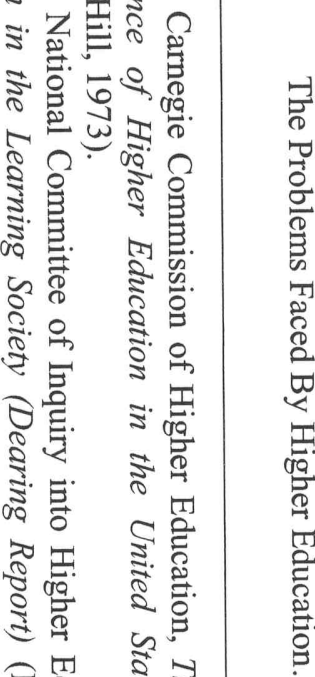

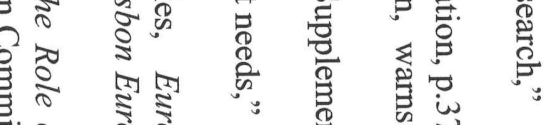
s: है है क्षे

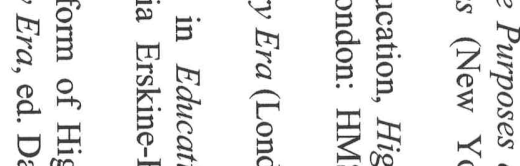

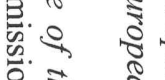

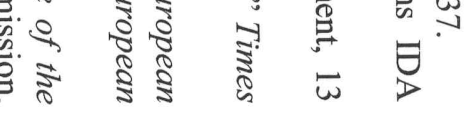
帚

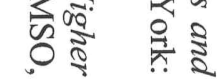

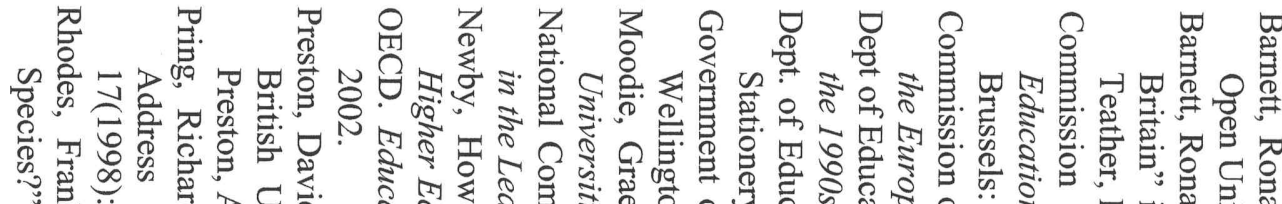

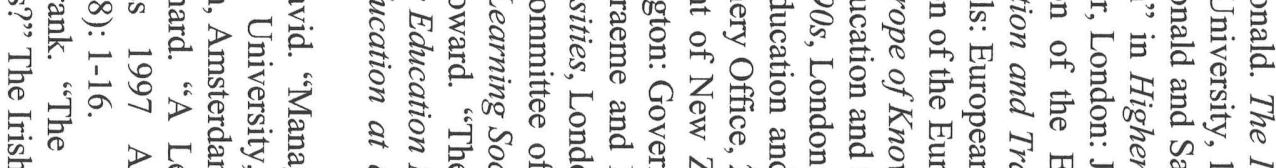

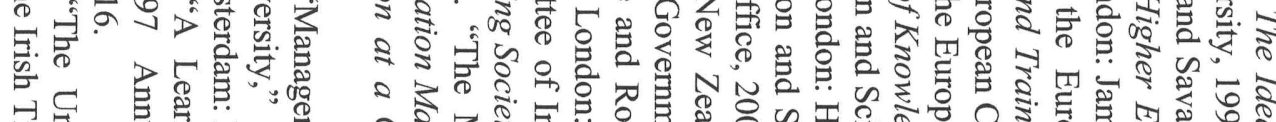

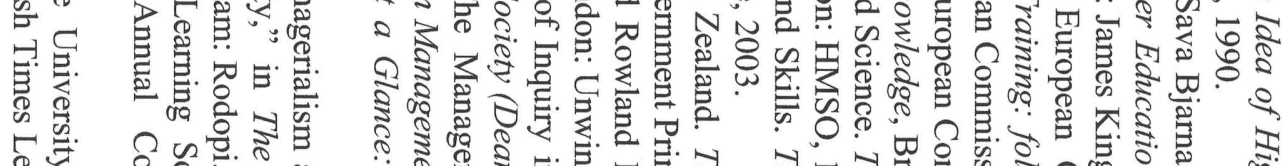

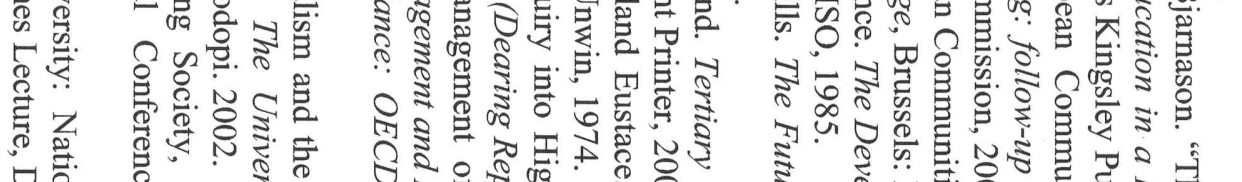

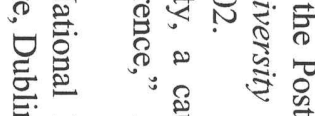

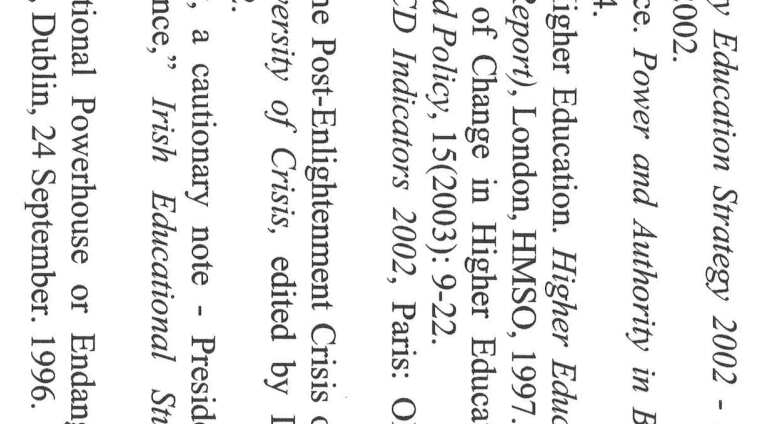

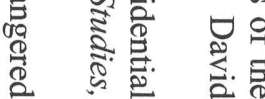
品

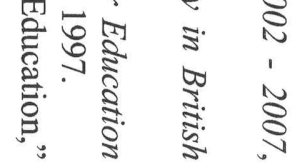
ㅎำ

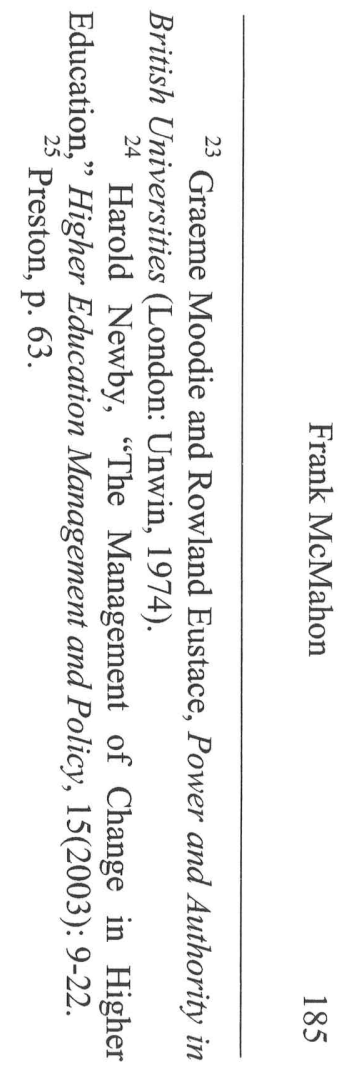




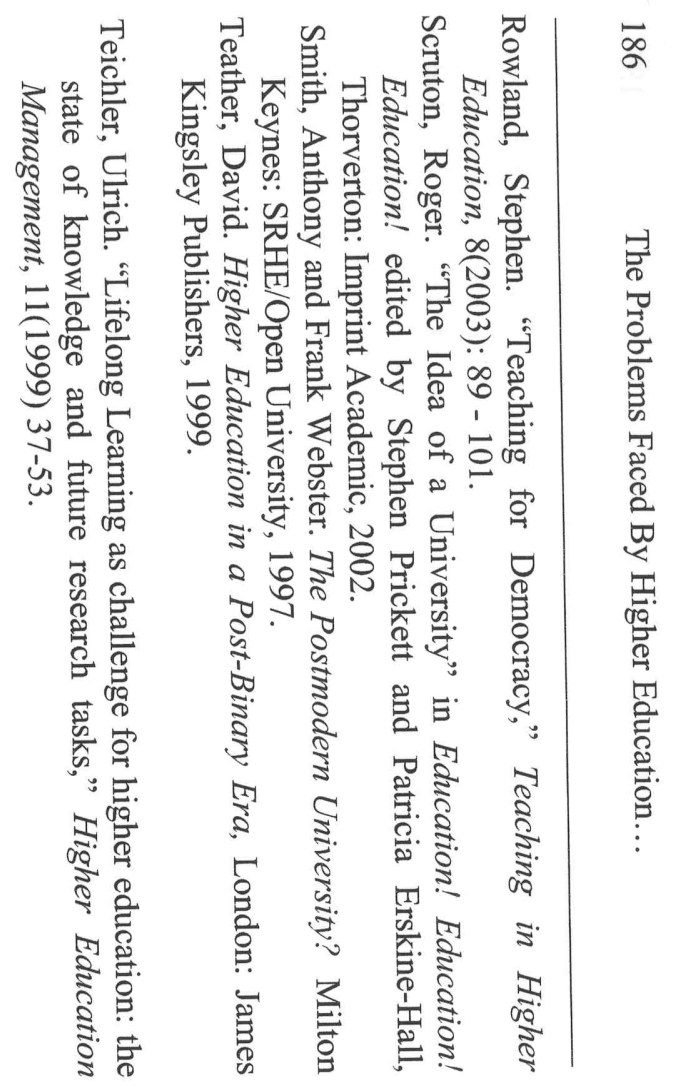

